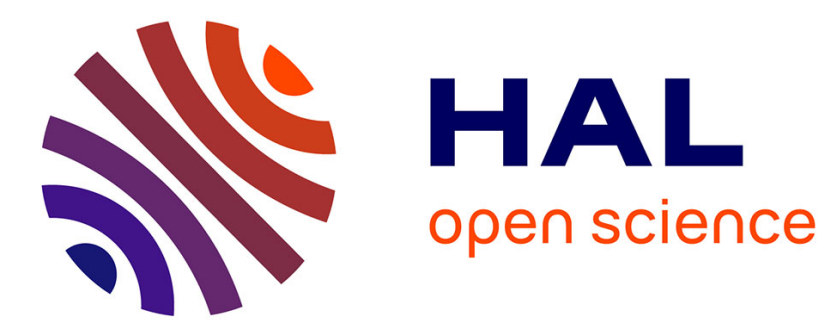

\title{
Remote sensing of phytoplankton groups in case 1 waters from global SeaWiFS imagery
}

Séverine Alvain, Cyril Moulin, Yves Dandonneau, Francois-Marie Breon

\section{To cite this version:}

Séverine Alvain, Cyril Moulin, Yves Dandonneau, Francois-Marie Breon. Remote sensing of phytoplankton groups in case 1 waters from global SeaWiFS imagery. Deep Sea Research Part I: Oceanographic Research Papers, 2005, 52 (11), pp.1989-2004. 10.1016/j.dsr.2005.06.015 . hal-00156839

\section{HAL Id: hal-00156839 \\ https://hal.science/hal-00156839}

Submitted on 22 Jun 2007

HAL is a multi-disciplinary open access archive for the deposit and dissemination of scientific research documents, whether they are published or not. The documents may come from teaching and research institutions in France or abroad, or from public or private research centers.
L'archive ouverte pluridisciplinaire HAL, est destinée au dépôt et à la diffusion de documents scientifiques de niveau recherche, publiés ou non, émanant des établissements d'enseignement et de recherche français ou étrangers, des laboratoires publics ou privés. 


\title{
REMOTE SENSING OF PHYTOPLANKTON GROUPS IN CASE 1 WATERS FROM GLOBAL SEAWIFS IMAGERY
}

\author{
S. Alvain ${ }^{1}$, C. Moulin ${ }^{1 *}$, Y. Dandonneau ${ }^{2}$, F.M. Bréon ${ }^{1}$ \\ ${ }^{1}$ IPSL/LSCE, CEA Saclay, 91191 Gif-sur-Yvette, France \\ ${ }^{2}$ IRD-IPSL/LOCEAN, 4 place Jussieu, 75252 Paris, France \\ * Corresponding author, E-mail: cyril.moulin@cea.fr, Fax: (33 1) 69087716
}

\begin{abstract}
Ocean color sensors enable a quasi-permanent monitoring of the chlorophyll $a$ concentration, $\mathrm{Chl} a$, in surface waters. This ubiquitous photosynthetic pigment cannot, however, be used to distinguish between phytoplankton species. Distinguishing phytoplankton groups from space is nevertheless necessary to better study some biochemical processes such as carbon fixation at the global scale, and is thus one of the major challenges of ocean color research. In situ data have shown that the water-leaving radiances $(\mathrm{nLw})$, measured by ocean color sensors at different wavelengths in the visible spectrum, vary significantly for a given Chl $a$. This natural variability is due partly to differences in optical properties of phytoplankton species. Here we derive relationships between $\mathrm{nLw}$ and phytoplankton species by using a large set of quantitative inventories of phytoplankton pigments collected during nine cruises from Le Havre (France) to Nouméa (New Caledonia) in the framework of the GeP\&CO program. Coincident SeaWiFS nLw data between 412 and $555 \mathrm{~nm}$ are extracted and normalized to remove the effect of $\mathrm{Chl} a$. These normalized spectra vary significantly with in-situ pigment composition, so that four major phytoplankton groups, i.e., haptophytes, Prochlorococcus, Synechococcus-like cyanobacteria and diatoms, can be distinguished. This classification (PHYSAT) is applied to the global SeaWiFS dataset for year 2001, and global maps of phytoplankton groups are
\end{abstract}


presented. Haptophytes and diatoms are found mostly in high latitudes and in eutrophic regions. Diatoms show a strong seasonal cycle with large-scale blooms during spring and summer. These results, obtained with only five channels in the visible spectrum, demonstrate that ocean color measurements can be used to discriminate between dominant phytoplankton groups provided that sufficient data are available to establish the necessary empirical relationships.

Keywords : Water color, Remote sensing, Phytoplankton, In situ measurements, SeaWiFS, Optical properties, Global, North Atlantic, Equatorial Pacific. 


\section{Introduction}

The ocean carbon cycle and associated carbon fluxes are partly controlled by marine biology. Phytoplankton cells use dissolved inorganic carbon to photosynthesize organic matter, which in turn is recycled in the water column or exported toward sediments. Properly modeling the phytoplankton growth in the global ocean is thus a prerequisite to the modeling of the marine carbon cycle. Our current knowledge of the geographical distribution and of the seasonal cycle of photosynthesizing marine organisms at the global scale comes mainly from satellite observations. The first spaceborne ocean color sensor, CZCS (Coastal Zone Color Scanner), was launched in 1978 and provided data until 1986. New sensors have been launched since, e.g., SeaWiFS (Sea Wide Field-of-view Sensor) in 1997 or MODIS (Moderate Resolution Imaging Spectroradiometer) in 1999 and in 2002, but the principle of ocean color algorithms did not change much in 25 years. After atmospheric correction, the blueto-green ratio of water-leaving radiances permits the estimation of the so-called "chlorophyll $a$ concentration" (Chl $a$ ) — actually the sum of the chlorophyll $a$ and pheophytin $a$ concentrations - which is used as a proxy for the phytoplankton (i.e., algae and photosynthetic cyanobacteria) biomass.

However, knowledge of $\mathrm{Chl} a$ is not sufficient to properly assess the photosynthesis contribution to the oceanic carbon cycle. Indeed all phytoplankton species contain chlorophyll $a$ (or its substitute divinyl chlorophyll $a$ ), but they have different requirements and produce different organic substances. Well-known examples are the $\mathrm{N}_{2}$ fixing cyanobacteria Trichodesmium, or the calcium carbonate fixing coccolithophorids. These two species have very specific optical properties that make them detectable from space (Brown et al., 1994 ; Subramaniam et al., 2002). Current ocean color algorithms, however, do not provide any information about other 
phytoplankton groups of primary importance to biogeochemical cycles. Diatoms, for instance, have a silica skeleton and export the organic matter toward sediments more efficiently than all other groups (Lochte et al., 1993), whereas prymnesiophytes produce dimethylsulfide (DMS), a compound that impacts the climate as a precursor of cloud condensation nuclei. Distinguishing phytoplankton species at the global scale from space is thus the next challenge for ocean color in case I waters (e.g., Kahru and Mitchell, 1998; Martin-Traykovski and Sosik, 1998; Moore et al., 2002; Morel, 1997; Sathyendranath et al. 2001; Sathyendranath et al., 2004).

Phytoplankton groups are generally characterized by some specific pigments — the biomarkers - and can thus be identified from pigment inventories derived from in situ samples. Such analysis requires an operator, whereas automatic optical measurements of the water absorption spectrum are tentatively used to retrieve information on the characteristics of the phytoplankton population (Stuart et al., 1998). However, it is often difficult to extract the contribution of each pigment to the measured absorption spectrum (Bricaud et al., 1995). The package effect can also modify the absorption spectrum and thus lead to a wrong interpretation in terms of phytoplankton species. The identification of phytoplankton groups from space is even more difficult, because the signal detected by an ocean color sensor depends also on the light backscattered by small detritus particles (Garver et al., 1994). Two different approaches can be used to retrieve phytoplankton groups from space: (1) perform large sets of in-water radiative computations with various amount of phytoplankton cells of different sizes, shapes and pigment compositions to simulate the ocean's inherent optical properties (Stramski et al., 2001) and to interpret its variability in terms of biological state of the phytoplankton population (Loisel et al., 2002); (2) use a large set of in situ pigment inventories with coincident ocean color spectral 
measurements to work out empirical relationships. Here we applied this latter approach to an unequalled set of in-situ measurements, performed in the framework of the GeP\&CO program in the Atlantic and the Pacific between 1999 and 2002, for which SeaWiFS data are available. The Gep\&Co program consists of simultaneous HPLC and spectrofluorometry pigment analysis performed five times a day during twelve 40-day cruises (October 1999 - July 2002) from Le Havre (France) to Nouméa (New Caledonia) onboard the merchant ship Contship London (Dandonneau et al., 2004).

\section{Data and methods}

\subsection{GeP\&CO}

Inventories of phytoplankton pigments are commonly used to discriminate between phytoplankton groups (Mackey et al., 1996; Vidussi et al., 2001; Barlow et al., 2002). The GeP\&CO (Geochemistry, Phytoplankton, and Color of the Ocean) program aims at describing and understanding the seasonal and inter-annual variability of phytoplankton populations in the North Atlantic and the tropical Pacific. The observations have been made quarterly, across the North Atlantic, along the eastern coast of the United States, through the Caribbean Sea to Panama, and across the equatorial and tropical South Pacific to New Zealand and New Caledonia (Dandonneau et al., 2004). As part of the routine measurements of GeP\&CO, surface water samples were taken every 4 hours, i.e. 5 times a day, so that 1502 pigment inventories were analyzed. This homogeneous data set, which covers a wide range of water types from the North Atlantic to the equatorial Pacific, provides a unique opportunity to link satellite observations and phytoplankton groups in the global ocean. 
Twenty-two pigments were measured on each sample by spectrofluorometry for chlorophyllous pigments and by HPLC for both chlorophyllous and carotenoid pigments. Spectrofluorometric measurements were made according to Neveux and Lantoine (1993), and the HPLC method was adapted from Goericke and Repeta (1993). Here we considered only 7 pigments, which are characteristic of the main phytoplankton groups that can be potentially found (Table 1). Note that for mono- and divinyl-chlorophyll $a$, we preferred spectrofluorimetry results because they were shown to be more accurate than HPLC ones during an inter-calibration exercise performed on some Gep\&Co samples with the Laboratoire d'Océanographie de Villefranche. Note also that we excluded the first three cruises from our database because of failures in the HPLC instrumentation, reducing the number of available pigment inventories to 1123 . Despite this, the GeP\&CO database remains unique in the sense that all measurements were made by a single operator and by the same protocols and techniques. The main characteristics of each GeP\&CO cruise are given in Table 2, and more details on the methodology can be found on the GeP\&CO web site at http://www.lodyc.jussieu.fr/gepco.

\subsection{SeaWiFS}

We used SeaWiFS Level 3 binned daily products provided by the NASA/GSFC/DAAC to get a set of $\mathrm{Chl} a$, aerosol optical thickness at $865 \mathrm{~nm}$, and normalized water-leaving radiances $(\mathrm{nLw})$ at 412, 443, 490, 510 and $555 \mathrm{~nm}$ that are coincident with GeP\&CO measurements. SeaWiFS normalized water-leaving radiances are outputs of the atmospheric correction (Gordon and Wang, 1994) and are used in turn to retrieve $\mathrm{Chl} a$ with the help of the OC4v4 bio-optical model, which relies on the ratio of the maximum $\mathrm{nLw}$ in blue bands (443, 490 or $510 \mathrm{~nm}$ ) to $\mathrm{nLw}$ at 
$555 \mathrm{~nm}$ (O'Reilly et al., 2000). Our objective is to show spectral changes of $\mathrm{nLw}$ related to pigments other than chlorophyll $a$ in order to use them as biomarkers of specific phytoplankton groups. To isolate this second order variation from the total $\mathrm{nLw}$ spectral variability, we defined a specific water-leaving radiance, $\mathrm{nLw}^{*}$, defined as:

$$
\operatorname{nLw}^{*}(\lambda)=\mathrm{nLw}(\lambda) / \mathrm{nLw}^{\mathrm{ref}}(\lambda, \operatorname{Chl} a)
$$

where $\mathrm{nLw}^{\text {ref }}$ is a simple model of $\mathrm{nLw}$ that accounts only for the SeaWiFS standard Chl $a$. Ideally, $\mathrm{nLw}^{\text {ref }}$ should have been the inverse function of the OC4v4 bio-optical model, but because this model is based on a choice between several $\mathrm{nLw}$ ratios, it cannot be inverted. We thus defined $\mathrm{nLw}^{\text {ref }}$ empirically from a large dataset of SeaWiFS Chl $a$ and nLw. This dataset of $28800 \mathrm{nLw}$ and Chl $a$ values was built with all SeaWiFS measurements available within $\pm 60 \mathrm{~km}$ and \pm 1 day around each GeP\&CO measurement performed during the GeP\&CO cruises. Mean values of $\operatorname{nLw}(\lambda)$ were computed for 26 narrow $\mathrm{Chl} a$ intervals (Figure 1), and a look-up table of $\mathrm{nLw}^{\mathrm{ref}}(\lambda, \mathrm{Chl} a)$ was generated. Note that because we used Level 3 binned products at $9 \mathrm{~km}$ resolution, which are obtained by averaging Level 2 GAC products at $4 \mathrm{~km}$ resolution, we verified that our $\mathrm{nLw}^{\text {ref }}$ spectra are consistent with SeaWiFS products by comparing the Chl $a$ retrieved using OC4v4 on our $\mathrm{nLw}^{\text {ref }}$ with the Level 3 binned Chl $a$.

A subset of SeaWiFS data was then extracted from the previous dataset of $28800 \mathrm{nLw}$ and Chl $a$ values by selecting only clear-sky pixels of the same day and located within an area of \pm 1 pixel around a GeP\&CO measurement, so that a maximum of 9 valid SeaWiFS pixels can be associated with each GeP\&CO measurement. We applied two additional criteria to keep only the highest quality SeaWiFS measurements: (1) the SeaWiFS aerosol optical thickness at $865 \mathrm{~nm}$ has to be lower than 0.15 in order to 
minimize the impact of atmospheric correction errors and of sub-pixel cloud contamination, and (2) the SeaWiFS Chl $a$ has to be lower than $3 \mathrm{mg} \cdot \mathrm{m}^{-3}$ to exclude possibly contaminated coastal waters, and higher than $0.04 \mathrm{mg} \cdot \mathrm{m}^{-3}$ to discard ultraoligotrophic waters where it is unlikely to find a dominant phytoplankton group in sea color data. For each GeP\&CO in situ observation, $\mathrm{nLw}^{*}(\lambda)$ was computed for all valid pixels using Equation 1, where $\mathrm{nLw}^{\text {ref }}$ was interpolated within the look-up table for the actual SeaWiFS Chl $a$. The mean and the standard deviation of $\mathrm{nLw}^{*}(\lambda)$ was then calculated using all valid pixels in order to associate only one $\mathrm{nLw}^{*}$ spectrum to a given Gep\&CO in situ observation. We thus applied a last selection criterion by removing data for which the standard deviation of $\mathrm{nLw}^{*}$ was larger than 0.1 , i.e., about $10 \%$ of $\mathrm{nLw}^{*}$, for at least one wavelength.

We ended up with a set of only 176 coincident GeP\&CO pigment inventories and "high quality" SeaWiFS $\mathrm{nLw}^{*}(\lambda)$. This relatively small number of coincident measurements (14\% of the initial GeP\&CO dataset) recalls the need for routine field measurements of phytoplankton pigment such as those performed during the GeP\&CO program. Note that we attempted to increase the number of coincident SeaWiFS measurements by increasing the search area to $4 \times 4$ pixels and the search period to \pm 1 day. By doing this, however, we found that, when several pixels were available, the standard deviation on $\mathrm{nLw}$ or Chl $a$ increases rapidly, which is unacceptable for our approach. Figure 2 nevertheless shows that this limited dataset is still representative of a wide range of locations, seasons and biophysical regimes, even in the North Atlantic, where many SeaWiFS pixels were not available because of the cloud coverage. Figure 3 also shows that $\mathrm{nLw}^{*}$ strongly varies in terms of both mean value and spectral shape within this reduced dataset. This observation confirms that the GeP\&Co dataset includes waters with a large variety of waters optical 
properties. We hereafter attempt to show relationships between SeaWiFS nLw ${ }^{*}$ and phytoplankton groups using co-located pigment inventories and SeaWiFS data.

\subsection{Identification of Phytoplankton Groups in GeP\&CO Measurements}

The objective of this section is to develop a method to associate a dominant phytoplankton group, if any, with each GeP\&CO pigment inventory. It is important to point out that, while there is a general agreement on the taxonomic message of each biomarker (e.g., divinyl chlorophyll $a$ is used to characterize Prochlorococcus), a large range of relative concentrations (pigments ratios) can be found in the literature. Pigment ratios, $\mathrm{P}_{\text {rel }}$, are defined as:

$$
\mathrm{P}_{\text {rel }}=\mathrm{P} /(\mathrm{Chl} a+\mathrm{d}-\mathrm{Chl} a)
$$

where $\mathrm{P}$ is the measured pigment concentration in the seawater and $\mathrm{d}-\mathrm{Chl} a$ is the concentration in divinyl chlorophyll $a$. Our interpretation of the 176 selected pigment inventories relies mostly on the bibliographic analysis performed by Mackey et al. (1996) for phytoplankton populations in equatorial and tropical waters and by Lampert (2001) for diatoms in the North Atlantic. Table 3 summarizes the relative concentrations of the major biomarkers for five main phytoplankton groups: diatoms, Prochlorococcus, haptophytes, Synechococcus-like cyanobacteria (SLC) and dinoflagellates. This table shows that, even for pure assemblages of phytoplankton, the relative concentration of the primary biomarker is highly variable except for divinyl-chlorophyll $a$. Table 3 thus shows that it is virtually impossible to define a single threshold for each biomarker.

This difficulty has been managed by assuming that all phytoplankton groups are represented within our dataset and by adjusting thresholds on the various biomarker concentrations, shown in Table 4, to obtain a set of coherent pigment inventories for 
each phytoplankton group. Fucoxanthin and $19^{\prime} \mathrm{HF}$ are used as primary biomarkers for diatoms and haptophytes, respectively, only when all other pigments were at low concentration. We did not impose any maximum threshold on these two biomarkers for the three other phytoplankton groups because these pigments are generally abundant in all GeP\&CO observations. An additional criterion on the Pheo $a / \mathrm{Chl} a$ ratio has been added in Table 4 to remove a few water samples that could have been affected by the degradation of organic matter. Note that thresholds in Table 4 are all within the range found in the literature (see Table 3). Note also that although we used the smallest peridinin relative concentration in Table 3, no pigment inventory was classified as dinoflagellates. This is not surprising since dinoflagellates are known to be present almost everywhere, but only as a minor component of the total phytoplankton population (Jeffrey et al., 1997). As a consequence only four assemblages (dominated respectively by diatoms, Prochlorococcus, haptophytes, and SLC) could be identified within the data set.

The criteria defined in Table 4 were used to classify the 176 pigment inventories for which a mean SeaWiFS nLw ${ }^{*}$ spectrum is available. Only 41 inventories, shown in Figure 4, were successfully classified; the others have been removed because they do not fulfill the pigment criteria of any phytoplankton group, suggesting only one quarter of the GeP\&CO samples was dominated by a single phytoplankton group. Note that although the diatom group is based on only three measurements, it was considered as significant because only "high-quality" SeaWiFS pixels were kept. Figure 4 shows that individual pigment inventories are well organized within each group and that the mean pigment compositions are clearly different for the four groups of phytoplankton. 


\subsection{Identification of Phytoplankton Groups in SeaWiFS Measurements}

The objective of this section is to assess whether the SeaWiFS nLw ${ }^{*}$ spectrum depends on the phytoplankton group identified from the water sample. Figure 5 shows that the $\mathrm{nLw}^{*}$ spectra associated with the 41 classified GeP\&CO pigment inventories are remarkably similar for a given phytoplankton group and differ significantly from one group to the other. This suggests that a relationship actually exists between both the spectral shape and the amplitude of the satellite signal and the dominant phytoplankton group, at least for the four groups identified within the GeP\&CO dataset. Haptophytes are characterized by low $\mathrm{nLw}^{*}$ values at any wavelength, with a particularly strong drop of $\mathrm{nLw}^{*}$ at 412 and $443 \mathrm{~nm}$. Prochlorococcus are associated to more neutral $\mathrm{nLw}^{*}$ spectra and to $\mathrm{nLw}^{*}$ values slightly below unity. SLC are characterized by $\mathrm{nLw}^{*}$ values above unity and by a slightly larger value of $\mathrm{nLw}^{*}$ at $412 \mathrm{~nm}$. Finally, Diatoms are detectable because of their high $\mathrm{nLw}^{*}$ values and their steep spectrum, which decreases from 412 to $510 \mathrm{~nm}$. From these results, a characteristic range of $\mathrm{nLw}^{*}(\lambda)$ was derived (Table 5). These criteria are broad enough to maximize the number of $\mathrm{nLw}^{*}$ spectra classified and narrow enough to avoid any overlapping between phytoplankton groups. Twenty six individual spectra out of 41 were thus successfully classified using these criteria. It is important to note that unclassified spectra are really "not classified" and not "misclassified", except for 4 individual Prochlorococcus spectra. 


\section{Preliminary Global Results}

The criteria defined in Table 5 were used to process SeaWiFS daily level 3 binned products at a resolution of $1 / 12^{\circ}(9 \mathrm{~km})$, available from the NASA/GSFC/DAAC web site. As a result, we obtained global monthly maps of phytoplankton groups at a resolution of $1^{\circ}$. The first step of the processing is to discard all pixels with an aerosol optical thickness greater than 0.15 or with a $\mathrm{Chl} a$ not in the range $[0.04,3] \mathrm{mg} \cdot \mathrm{m}^{-3}$. For each remaining pixel, Equation 1 is applied to derive $\mathrm{nLw}^{*}$ from $\mathrm{nLw}$ and $\mathrm{Chl} a$ at the five wavelengths. The criteria defined in Table 5 are then used to identify the dominant phytoplankton group. Pixels with a nLw ${ }^{*}$ spectrum that cannot be classified within one of the four phytoplankton groups are still considered as valid and are associated with an additional group of "unidentified phytoplankton assemblages". Assuming that a phytoplankton group usually prevails at least for a few weeks, we used the daily phytoplankton group maps at a resolution of $1 / 12^{\circ}$ to generate monthly maps at a $1^{\circ}$ resolution by selecting the group that had been retrieved for at least half of the valid (including unidentified) pixels within each $1^{\circ} \times 1^{\circ}$ grid box. Note that no phytoplankton group is assigned to a grid box for which no phytoplankton group dominates or for which unidentified pixels prevail. This method to assign phytoplankton dominant groups to SeaWiFS pixels will be mentioned hereafter as PHYSAT. Note finally that the assumption of a prevailing phytoplankton group at the monthly scale may not apply in some specific conditions (e.g., transient blooms or brief episodes in regions with highly variable currents will not appear in monthly maps) but is likely valid in most cases.

Figure 6 compares monthly maps of phytoplankton groups with monthly mean maps of Chl $a$ for year 2001. Global results of PHYSAT show well defined and persistent 
large-scale structures characterized to the first order by the dominance of Prochlorococcus and SLC groups in oligotrophic tropical waters, whereas haptophytes and diatoms prevail in the eutrophic waters of high latitudes. A clear seasonal cycle is also evidenced at high latitudes, where haptophytes dominate in winter and large-scale diatom blooms occur in summer. The extent of these diatom blooms is particularly large in the Southern Ocean during January. Some regions such as the northern Indian Ocean and the equatorial Atlantic are widely covered by unidentified pixels due to the quasi-permanent presence of high aerosol optical thicknesses, whereas the large patches of unidentified pixels in the Southern Ocean are likely due to the presence of undetected species, as discussed in section 4. Outside of these well-defined regions, unidentified pixels are relatively rare in Figure 6. This demonstrates that SeaWiFS data extracted along the GeP\&CO shipping track account for most of the worldwide variability of $\mathrm{nLw}^{*}$.

Since PHYSAT was developed using only $15 \%$ of GeP\&CO field data, the extensive analysis of the whole dataset performed by Dandonneau et al. (2004) can be used to validate the maps shown in Figure 6. Their analysis shows phytoplankton species distributions on the ship track between Le Havre and New York that are consistent with our results, with relatively rich waters dominated by haptophytes in January and dominated by diatoms in spring. On the ship track between Panama and Tahiti, Dandonneau et al. (2004) show that Prochlorococcus and SLC are the dominant species all year long, a result consistent with Figure 6. Measurements performed during the Atlantic Meridional Transect (AMT) cruises (Gibb et al., 2000) in 1996 and 1997 can also be used to validate our global results. Fucoxanthin concentrations measured during these cruises show the presence of diatoms north of $40^{\circ} \mathrm{N}$ in AprilMay and south of $40^{\circ} \mathrm{S}$ in September-October, which is consistent with Figure 6. 
Similarly, the distribution of nanoflagellates, which is equivalent to our haptophyte species, during AMT cruises shows a maximum at high latitudes when diatoms do not prevail. AMT zeaxanthin and divinyl chlorophyll $a$ concentrations also confirm our results by showing the dominance of both Prochlorococcus and SLC at low latitudes. This result has also been confirmed by flow cytometry counts of Synechococcus and Prochlorococcus (Zubkhov et al., 1998).

Figure 6 also shows that our results are in good agreement with the long term monitoring of phytoplankton communities performed at two historic stations: DYFAMED in the western Mediterranean and BATS in the Sargasso Sea. In the northwestern Mediterranean, the phytoplankton biomass is dominated all year long by Haptophytes (in blue in Figure 6), except during the stratified summertime period, which is often characterized by a high of prochlorophytes (in green in Figure 6) (Marty et al., 2002). A similar agreement is found with the dynamic of phytoplankton populations observed at the BATS station, with a dominance of prymnesiophytes from January to early summer, followed by high concentrations of Prochlorococcus during summer (DuRand et al, 2001, Steinberg et al, 2001).

The comparison of PHYSAT results with standard SeaWiFS maps shows that high Chl $a$ are associated mostly with diatoms, as expected, or with haptophytes. There is, however, no strong correlation between phytoplankton group and $\mathrm{Chl} a$ maps in Figure 6. On the contrary Figure 7 shows that a large range of SeaWiFS Chl $a$ is associated with each phytoplankton group, indicating that chlorophyll-a alone is not sufficient to identify a phytoplankton assemblage. Some expected relationships between chlorophyll concentration and phytoplankton assemblage, however, appear in Figure 7: diatoms are always associated with high Chl $a$ values, whereas very low Chl $a$ concentrations $\left(<0.07 \mathrm{mg} \cdot \mathrm{m}^{-3}\right)$ are always associated with Prochloroccus. For 
Chl $a$ concentration between 0.1 and $0.3 \mathrm{mg} . \mathrm{m}^{-3}$, i.e., for a large fraction of the global ocean (see Figure 6), almost all phytoplankton groups have an approximately equal contribution.

\section{Discussion}

The global variability of marine phytoplankton is presented here using only four groups, or assemblages. This is much less than the number of taxonomic groups identified in the oceans. For instance, cryptophytes, chrysophytes, and chlorophytes are not considered here. In addition, important groups such as the $\mathrm{N}_{2}$-fixing Trichodesmium or the calcium carbonate fixing coccolithophorids have been missed by the present study. This is partly due to the specificities of the GeP\&CO sampling. In spite of a seasonal coverage from $\sim 50^{\circ} \mathrm{N}$ to $35^{\circ} \mathrm{S}$ and of the wide variety of oceanic regimes sampled, the cruises did not sample intense blooms of Trichodesmium or coccolithophorids. We also did not consider in this study carotenoid pigments such as alloxanthin or prasinoxanthin, which are unambiguous biomarkers of cryptophytes and prasinophytes, respectively, but are never abundant, entailing large relative measurement errors.

As shown in section 3, PHYSAT often fails in classifying pixels at high latitudes, particularly in the Southern Ocean, where large unidentified patches are observed. The presence of phytoplankton assemblages with specific optical properties (such as coccolithophorids or Phaeocystis blooms), which were not sampled during GeP\&CO cruises, may explain the large number of unclassified pixels. This hypothesis has to be validated, but it seems unlikely that a bias in SeaWiFS nLw, due for example to a low sun elevation, affects our results in some patches because patches of diatoms and haptophytes are successfully identified elsewhere at the same latitude. It is finally 
important to note that the relationships proposed here to associate $\mathrm{nLw}^{*}$ spectra with phytoplankton groups are purely empirical and raise questions about their bio-optical interpretation. Indeed, former studies based on absorption measurements suggest that, contrary to what is shown in this work, it is impossible to detect phytoplankton groups from space (e.g., Garver et al., 1994).

This apparent contradiction suggests that satellite normalized water-leaving radiances are not sensitive solely to the absorption coefficient of the phytoplankton. Indeed $\mathrm{nLw}$ depends also on backscattering characteristics of phytoplankton cells and of other water constituents, such as phytoplankton detritus, zooplankton detritus and colored dissolved organic matter. While the phytoplankton backscattering coefficient is generally almost spectrally neutral, its mean value may strongly vary from one species to the other (Bricaud et al., 1988; Stramski et al., 2001; Vaillencourt et al., 2004). It is thus likely that backscattering properties explain the observed differences in $\mathrm{nLw}^{*}$ mean value at all wavelengths in Table 5 and Figure 5, whereas absorption is responsible for the observed differences in $\mathrm{nLw}^{*}$ spectral shape between 412 and 490 nm. This interpretation would, however, have to be confirmed, for example by comparing our maps of dominant species to available maps of both absorption and backscattering coefficients (Loisel and Stramski, 2000; Loisel et al., 2002). Besides, the classes of $\mathrm{nLw}^{*}$ would also have to be compared with theoretical spectra computed from a radiative transfer model in which specific inherent optical properties are used for each phytoplankton group (Stramski et al., 2001).

\section{Conclusion}

We used coincident SeaWiFS spectral normalized water-leaving radiances and pigment inventories collected in the framework of the GeP\&CO program to 
investigate the relationships between phytoplankton groups and satellite measurements. We first defined the specific normalized water-leaving radiance, $\mathrm{nLw}{ }^{*}$, to analyze the second order spectral variability of satellite ocean color measurements, which is likely related to the characteristics of the ecosystem. In parallel, we developed a classification based on seven phytoplankton pigments to associate a dominant phytoplankton group, if any, with each GeP\&CO pigment inventory. The comparison between the two datasets shows that the main phytoplankton groups are related to a specific $\mathrm{nLw}^{*}$ spectral signature that can be used to identify phytoplankton assemblages at the global scale. These principles form the basis of PHYSAT.

Such an approach requires a very large and diverse collection of in-situ data. Indeed in the large initial GeP\&CO dataset (1123 measurements), only 41 pigment inventories were finally useable to define the relationships between $\mathrm{nLw}^{*}$ and phytoplankton groups. Most of the measurements were discarded because there was no coincident SeaWiFS pixel, or because the in situ pigment inventories did not show any dominant phytoplankton group. This demonstrates the importance of long-term and large-scale measurements for future improvements of ocean color algorithms.

SeaWiFS daily level 3 binned products maps for year 2001 were processed and yielded global monthly maps of phytoplankton groups, which are spatially coherent and in agreement with our current knowledge of phytoplankton group distributions, both in terms of seasonality and spatial variability. This work essentially demonstrates that remote sensing of marine ecosystems is possible, even with a relatively simple ocean color sensor like SeaWiFS. The SeaWiFS archive covers seven years, a period that is long enough to study the time (seasonal, inter-annual) and space variability of phytoplankton assemblages in relation with major climate phenomena such as El Niño. Further improvements of the method would certainly be possible with more 
accurate multi-spectral (e.g., MODIS and MERIS) or forthcoming hyper-spectral sensors. Other remarkable phytoplankton species such as coccolithophorids, Phaeocystis or Trichodesmium, which are known for their specific normalized waterleaving radiance spectra, may be added to our classification of ocean color imagery.

Acknowledgements: GeP\&CO is part of the French PROOF (Processus Biogéochimiques dans l'Océan et Flux) program, granted by INSU/CNRS, IRD, and CNES. We thank NASA/GSFC/DAAC for providing access to daily L3 SeaWiFS binned products. H. Loisel is acknowledged for his pertinent comments. We thank Hervé Claustre and Joséphine Ras, who made possible a comparison of the GeP\&CO pigment measurement methods with their high quality HPLC measurements. We are grateful to the owners and crew of MS Contship London, who kindly offered excellent sampling conditions throughout the GeP\&CO cruises.

\section{References.}

Barlow, R. G., Aiken J., Holligan P. M., Cummings D. G., Maritorena S., and Hooker S., 2002. Phytoplankton pigment and absorption characteristics along meridional transects in the Atlantic Ocean, Deep-Sea Res. I, 47, 637-660.

Bricaud, A. Bedhomme A-L. and Morel A., 1988. Optical properties of diverse phytoplanktonic species: experimental results and theoretical interpretation, $J$. Plankton Res., 10, 851-873.

Bricaud, A., Babin M., Morel A., and Claustre H., 1995. Variability in the chlorophyll-specific absorption coefficients of natural phytoplankton: Analysis and parameterization, J. Geophys. Res., 100, 13321-13332.

Brown, C. W. and Yoder J. A., 1994. Coccolithophorid blooms in the global ocean. $J$. Geophys. Res., 99, 7467-7482.

Dandonneau, Y., Deschamps P.-Y., Nicolas J.-M., Loisel H., Blanchot J., Montel Y., Thieuleux F., and Bécu G., 2004. Seasonal and interannual variability of ocean color and composition of phytoplankton communities in the North Atlantic, Equatorial Pacific and South Pacific, Deep-Sea Res. II, 51,303-318. 
DuRand, M.D., Olson R.J. and Chisholm S.W., 2001. Phytoplankton population dynamics at the Bermuda Atlantic Time-Series station in the Sargasso Sea. Deep-Sea Res. II, 48, 1983-2003.

Garver, S. A., Siegel D. A., and Mitchell B. G., 1994. Variability in near-surface particulate absorption spectra: What can a satellite ocean color imager see? Limnol. Oceanogr. 39, 1349-1367.

Goericke, R. and Repeta D. J., 1993. Chlorophylls a and b and divinyl chlorophylls a and $\mathrm{b}$ in the open subtropical North Atlantic Ocean. Mar. Ecol. Progr. Series 101, 307-313.

Gibb, S. W., Barlow R. G., Cummings D. G., Rees N. W., Trees C. C., Holligan P. and Suggett D., 2000. Surface phytoplankton pigment distributions in the Atlantic Ocean: an assessment of basin scale variability between $50^{\circ} \mathrm{N}$ and $50^{\circ} \mathrm{S}$, Progress in Oceanography, 45, 339-368.

Gordon, H. R. and Wang M., 1994. retrieval of water-leaving radiance and aerosol optical thickness over the oceans with SeaWiFS: A preliminary algorithm, Appl. Opt., 33, 443-452.

Jeffrey, S. W., Mantoura R. F. C. and Wright S. W., 1997. Phytoplankton pigments in oceanography, UNESCO, $661 \mathrm{pp}$.

Kahru, M. and Mitchell B. G., Spectral reflectance and absorption of a massive red tide off Southern California. J. Geophys. Res., 103, 21601-21609, 1998.

Lampert, L., 2001. Dynamique saisonnière et variabilité pigmentaire des populations phytoplanctoniques dans l'Atlantique Nord (golfe de Gascogne), Ph.D. Thesis, Univ. Bretagne Occidentale, 294 pp.

Lochte, K., Ducklow H. W., Fasham M. J. R. and Stienens C., 1993. Plankton succession and carbon cycling at $47^{\circ} \mathrm{N} 20^{\circ} \mathrm{W}$ during the JGOFS North Atlantic Bloom Experiment, Deep-Sea Res. II, 40, 91-114.

Loisel, H. and Stramski D., 2000. Estimation of the inherent optical properties of natural waters from the irradiance attenuation coefficient and reflectance in the presence of Raman scattering, Appl. Opt., 39, 3001-3011.

Loisel, H., Nicolas J.-M., Deschamps P.-Y. and Frouin R., 2002. Seasonal and interannual variability of particulate organic matter in the global ocean, Geophys. Res. Lett., 29, 49-52.

Mackey, M. D., Mackey D. J., Higgins H. W. and Wright S. W., 1996. CHEMTAX - A program for estimating class abundances from chemical markers: 
Application to HPLC measurements of phytoplankton, Ecology Progress Series, 144, 265-283.

Martin-Traykovski, L. and Sosik H. M., 1998. Optical Classification of Water Types based on Remotely-Sensed Ocean Colour, In Proc. of Ocean Optics XIV Conf., 10-13 Nov., Kailua-Kona, Hawaii.

Marty J.-C., Chiavérini J., Pizay M.-D. and Avril B., 2002. Seasonal and interannual dynamics of nutrients and phytoplankton pigments in the western Mediterranean Sea at the DYFAMED time-series station (1991-1999), Deep-Sea Res. II, 49, 1965-1985.

Moore, T. S., Campbell J. W., Dowell M. D., 2002. Linking algal functional groups with bio-optical provinces on a global scale, In Proc. of Ocean Optics XVI Conf., 18-22 Nov., Santa Fe, New Mexico.

Morel, A., 1997. Consequences of a Synechococcus bloom upon the optical properties of oceanic Case 1 waters, Limnol. Oceanogr., 42, 1746-1754.

Neveux, J., and Lantoine F., 1993. Spectrofluorometric assay of chlorophylls and phaeopigments using the least squares approximation technique. Deep-Sea Res I, 40, 1747-1765.

O'Reilly, J. E., et al., Ocean color chlorophyll-a algorithms for SeaWiFS, OC2 and OC4 : Version 4, SeaWiFS Postlaunch Technical Report Series, Vol.11, Part 3, NASA/TM-2000-206892, 2000.

Sathyendranath, S., Cota G., Stuart V., Maass H. and Platt T., 2001. Remote sensing of phytoplankton pigments: a comparison of empirical and theoretical approaches, Int. J. Remote Sens., 22, 249-273.

Sathyendranath, S., Watts L., Devred E., Platt T., Caverhill C.and Maass H., 2004. Discrimination of diatoms from other phytoplankton using ocean color data, Mar. Ecol. Prog. Ser., 272, 59-68.

Steinberg, D. K., Carlson C. A., Bates N. R., Johnson R. J., Michaels A. F. and Knap A. H., 2001. Overview of the US JGOFS Bermuda Atlantic Time-series Study (BATS): a decade-scale look at ocean biology and biogeochemistry. Deep-Sea Res. II, 48, 1405-1447.

Stramski, D., Bricaud A. and Morel A., 2001. Modeling the inherent optical properties of the ocean based on the detailed composition of the planktonic community, Appl. Opt., 40, 2929-2945. 
Stuart, V., Sathyendranath S., Platt T., Maass H. and Irwin B. D., 1998. Pigments and species composition of natural phytoplankton populations: effect on the absorption spectra, J. Plankton Res., 20, 187-217.

Subramaniam, A., Brown C. W., Hood R. R., Carpenter E. J. and Capone D. G., 2002. Detecting Trichodesmium blooms in SeaWiFS imagery, Deep Sea Res. II, 49, 107-121.

Vaillencourt, R., Brown C.W., Guillard R.L. and Balch W.M., 2004. Light backscattering properties of marine phytoplankton: relationships to cell size, chemical composition and taxonomy, J. Plankton Res., 26, 191-212.

Vidussi, F., Claustre H., Manca B. B., Luchette A.and Marty J.-C., 2001. Phytoplankton pigment distribution in relation to upper thermocline circulation in the eastern Mediterranean Sea during winter, J. Geophys. Res., 106, 1993919956.

Zubkhov, M. V., Sleigh M. A., Tarran G. A., Burkhill P. H., Leakey R. J. and Raymond J. G., 1998. Picoplanktonic community structure on an Atlantic transect from $50^{\circ} \mathrm{N}$ to $50^{\circ} \mathrm{S}$, Deep-Sea Res. I, 45, 1339-1355. 


\section{Figures}

Figure 1 Normalized water leaving radiance $\mathrm{nLw}$ as a function of wavelength for various chlorophyll-a. Average spectra were obtained from 28800 coincident SeaWiFS chlorophyll a concentration and $\mathrm{nLw}$ spectra located in the vicinity of the GeP\&CO ship tracks.

Figure 2. Maps of the selected GeP\&CO measurements for a) July to September, b) October to December, c) January to March and d) April to June.

Figure 3. Spectral shapes of $\mathrm{nLw}^{*}$ for the selected GeP\&CO measurements in a) January to March, b) April to June, c) July to September, and d) October to December.

Figure 4. Individual pigment inventories (see Table 1) for the four populations identified, dominated by: a) haptophytes, b) Prochlorococcus, c) SLC, and d) diatoms. Grey bars represent the mean pigment relative concentrations, and black dots show the individual pigment relative concentrations.

Figure 5. Spectral signatures of $\mathrm{nLw}^{*}$ of the four different phytoplankton assemblages, dominated by a) haptophytes, b) Prochlorococcus, c) SLC, and d) diatoms. Individual SeaWiFS $\mathrm{nLw}^{*}$ are depicted by the grey lines. Bold plain lines show the minimum and maximum spectral values of $\mathrm{nLw}^{*}$ defined in Table 5 to characterize phytoplankton groups.

Figure 6. Monthly mean maps of the phytoplankton assemblages (left panels with haptophytes in blue, Prochlorococcus in green, SLC in yellow, and diatoms in red) and of the standard SeaWiFS Chl $a$ (right panels) for January, April, June, August and October 2001. Unidentified pixels are in black.

Figure 7. Relative frequency histogram of the SeaWiFS Chl $a$ for year 2001 for the four different phytoplankton assemblages, dominated by: a) haptophytes, b) Prochlorococcus, c) SLC, and d) diatoms. 


\section{Tables}

\begin{tabular}{|c|c|c|c|c|c|c|c|}
\hline & Chlorophyll-a & Divinyl Chlorophyll-a & Pheophytin-a & Fucoxanthin & Peridinin & $\begin{array}{l}\text { 19'-Hexanoylo- } \\
\text { xyfucoxanthin }\end{array}$ & Zeaxanthin \\
\hline Notation & Chl $a$ & Div $a$ & Pheo $a$ & fucox & perid & $19^{\prime} \mathrm{HF}$ & Zeax \\
\hline Method & Spectrofluo & Spectrofluo & Spectrofluo & HPLC & HPLC & HPLC & HPLC \\
\hline $\begin{array}{c}\text { Taxonomic } \\
\text { message }\end{array}$ & $\begin{array}{l}\text { All, except } \\
\text { Prochloro- } \\
\text { coccus }\end{array}$ & $\begin{array}{l}\text { Prochloro- } \\
\text { coccus }\end{array}$ & Degradation & Diatoms & $\begin{array}{c}\text { Dinofla- } \\
\text { gellates }\end{array}$ & $\begin{array}{l}\text { Prymnesio- } \\
\text { phytes }\end{array}$ & $\begin{array}{c}\text { SLC } \\
\text { Prochloro- } \\
\text { coccus }\end{array}$ \\
\hline
\end{tabular}

Table 1. Description of the 7 phytoplankton pigments used in this study (summarized from Jeffrey et al., 1997). 


\begin{tabular}{|c|c|c|c|c|c|c|c|c|c|}
\hline & $\mathbf{D}$ & $\mathbf{E}$ & $\mathbf{F}$ & $\mathbf{G}$ & $\mathbf{H}$ & $\mathbf{I}$ & $\mathbf{J}$ & $\mathbf{K}$ & $\mathbf{L}$ \\
\hline Period & $23 / 07 / 00$ & $16 / 10 / 00$ & $15 / 01 / 01$ & $10 / 04 / 01$ & $09 / 07 / 01$ & $03 / 10 / 01$ & $01 / 01 / 02$ & $30 / 03 / 02$ & $25 / 06 / 02$ \\
& $25 / 08 / 00$ & $20 / 11 / 00$ & $16 / 02 / 01$ & $13 / 05 / 01$ & $12 / 08 / 01$ & $07 / 11 / 01$ & $06 / 02 / 02$ & $04 / 05 / 02$ & $01 / 09 / 02$ \\
\hline $\begin{array}{c}\text { Number of selected } \\
\text { measurements }\end{array}$ & 17 & 18 & 23 & 18 & 20 & 23 & 17 & 15 & 25 \\
\hline
\end{tabular}

Table 2. Description of the nine cruises used in this study. 


\begin{tabular}{|c|c|c|c|c|c|}
\hline & Div $\boldsymbol{a}$ & perid & fucox & 19'HF & zeax \\
\hline Diatoms & & & $0.15-0.80$ & & \\
\hline Prochlorococcus & 1.00 & & & & $0.15-0.35$ \\
\hline Haptophytes & & & & $0.10-1.40$ & \\
\hline SLC & & & & & $0.10-0.60$ \\
\hline Dinoflagellates & & $0.10-1.00$ & & & \\
\hline
\end{tabular}

Table 3. Mean relative concentration of the main biomarkers for the most frequent phytoplankton groups. 


\begin{tabular}{|c|c|c|c|c|c|c|}
\hline & Pheo $\boldsymbol{a}$ & Div $\boldsymbol{a}$ & perid & fucox & 19'HF & zeax \\
\hline Diatoms & $<0.30$ & $<0.40$ & $<0.10$ & $\mathbf{> 0 . 1 8}$ & - & $<0.20$ \\
\hline Prochlorococcus & $<0.30$ & $>\mathbf{0 . 4 0}$ & $<0.10$ & - & - & $>\mathbf{0 . 3 5}$ \\
\hline Haptophytes & $<0.30$ & $<0.40$ & $<0.10$ & - & $\mathbf{0 0 . 1 4}$ & $<0.20$ \\
\hline SLC & $<0.30$ & $<0.40$ & $<0.10$ & - & - & $>\mathbf{0 . 2 0}$ \\
\hline Dinoflagellates & $<0.30$ & $<0.40$ & $\mathbf{> 0 . 1 0}$ & - & - & $<0.20$ \\
\hline
\end{tabular}

Table 4. Thresholds used in this study to associate a relative pigment concentration inventory to a specific phytoplankton group. Values in bold correspond to the primary biomarkers shown in Table 3. 


\begin{tabular}{|c|ccccc|l|}
\hline & $\mathbf{4 1 2}$ & $\mathbf{4 4 3}$ & $\mathbf{4 9 0}$ & $\mathbf{5 1 0}$ & $\mathbf{5 5 5}$ & Additional criteria \\
\hline Haptophytes min. & 0.4 & 0.55 & 0.6 & 0.6 & 0.6 & $\mathrm{nLw}(412)<\mathrm{nLw}^{*}(443)$ \\
Haptophytes max. & 0.8 & 0.9 & 0.95 & 1.0 & 1.0 & $\mathrm{nLw}(443)<\mathrm{nLw}^{*}(490)$ \\
\hline Prochlorococcus min. & 0.8 & 0.85 & 0.85 & 0.85 & 0.8 & \\
Prochlorococcus max. & 1.0 & 1.0 & 1 & 1.0 & 1.0 & \\
\hline SLC min. & 1.0 & 0.95 & 0.9 & 0.9 & 0.9 & $\mathrm{nLw}(412)>\mathrm{nLw}^{*}(443)$ \\
SLC max. & 1.3 & 1.2 & 1.2 & 1.2 & 1.2 & $\mathrm{nLw}(412)>\mathrm{nLw}^{*}(490)$ \\
\hline Diatoms min. & 1.3 & 1.2 & 1.1 & 1.1 & 1.1 & $\mathrm{nLw}(412)>\mathrm{nLw}^{*}(490)$ \\
Diatoms max. & 2.4 & 2 & 1.7 & 1.6 & 1.6 & $\mathrm{nLw}(490)>\mathrm{nLw}^{*}(555)$ \\
\hline
\end{tabular}

Table 5. Characteristics of acceptable $\mathrm{nLw}^{*}$ spectra for each phytoplankton group. 


\section{Figure 1}

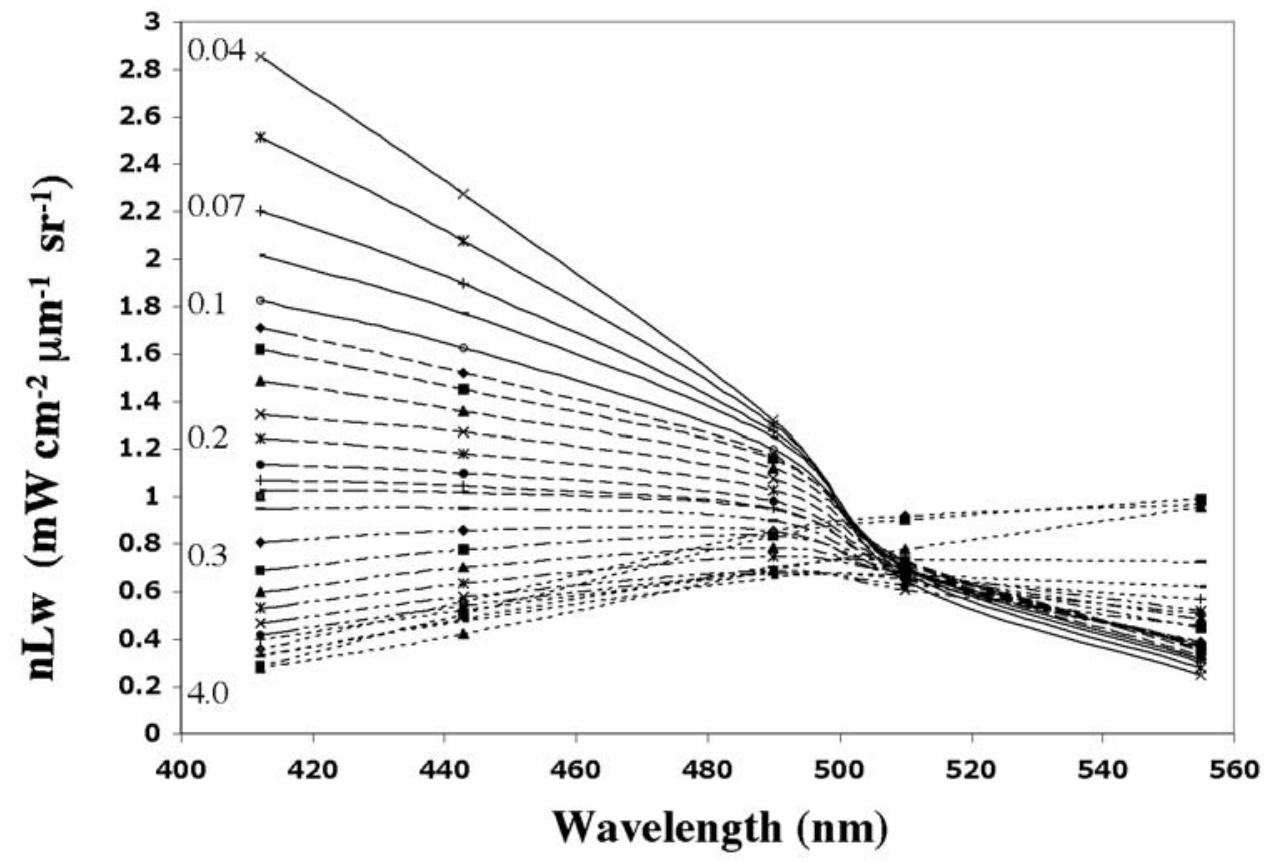

Figure 1 Normalized water leaving radiance $\mathrm{nLw}$ as a function of wavelength for various chlorophyll-a. Average spectra were obtained from 28800 coincident SeaWiFS chlorophyll a concentration and $\mathrm{nLw}$ spectra located in the vicinity of the GeP\&CO ship tracks. 


\section{Figure 2}
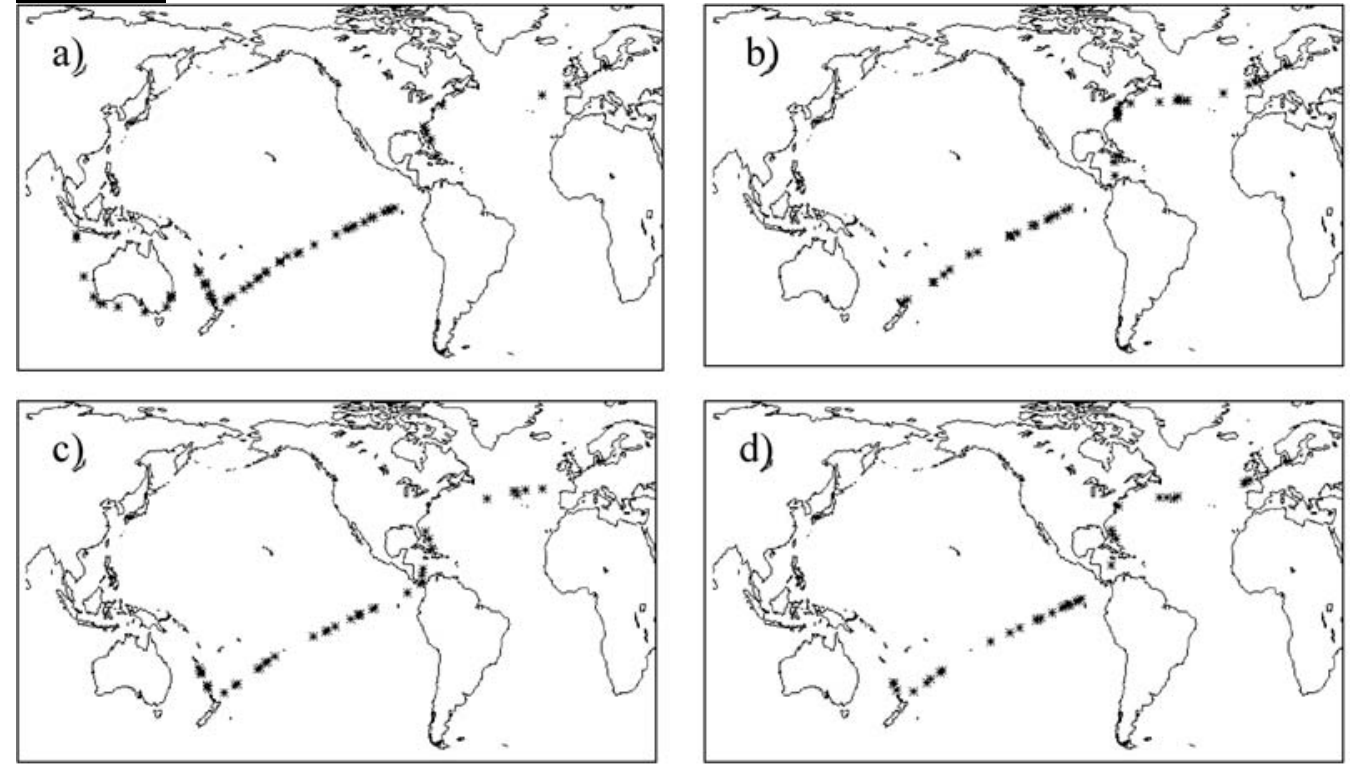

Figure 2. Maps of the selected GeP\&CO measurements for a) July to September, b) October to December, c) January to March and d) April to June. 
Figure 3
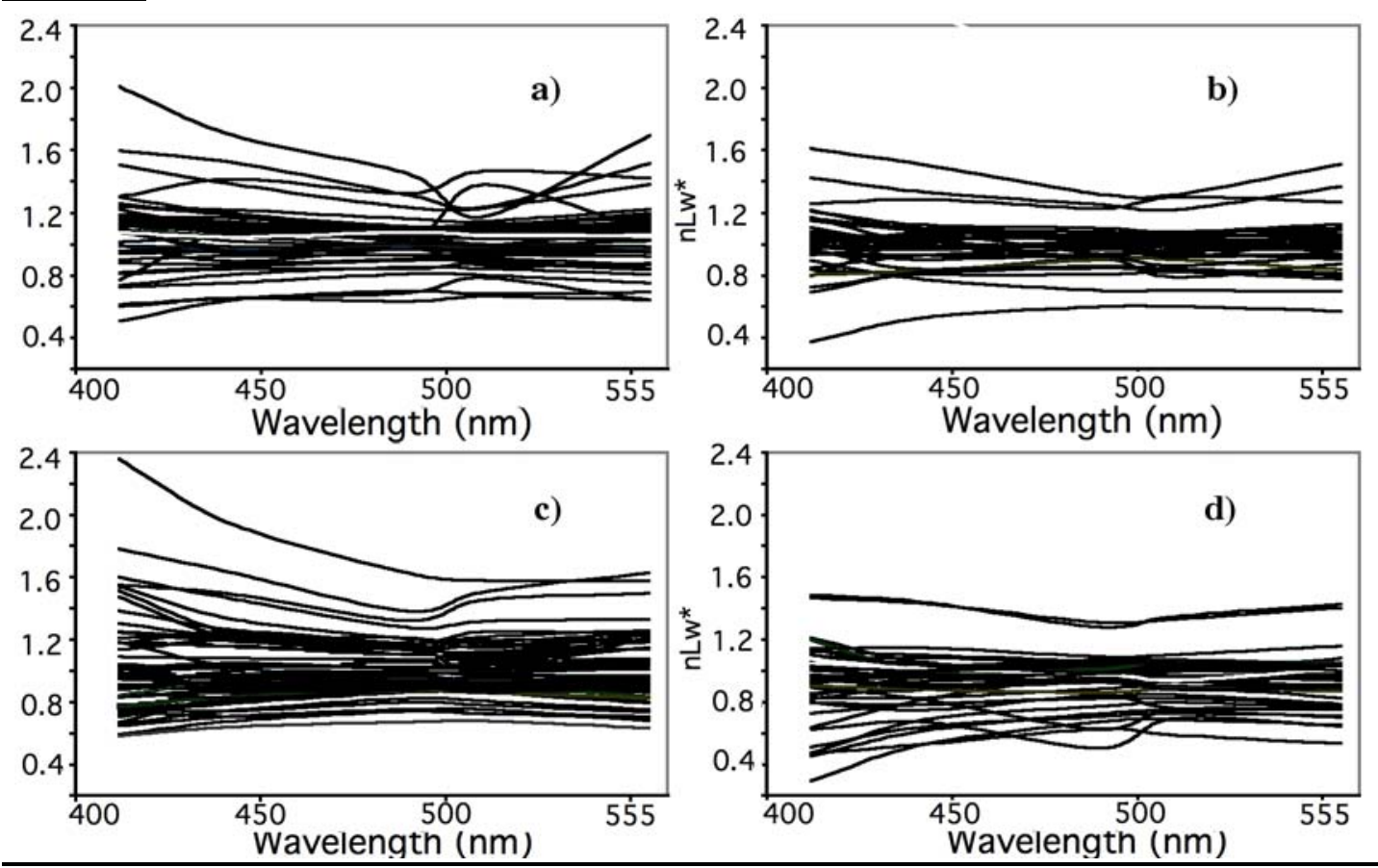

Figure 3. Spectral shapes of $\mathrm{nLw}^{*}$ for the selected GeP\&CO measurements in a) January to March, b) April to June, c) July to September, and d) October to December. 
Figure 4
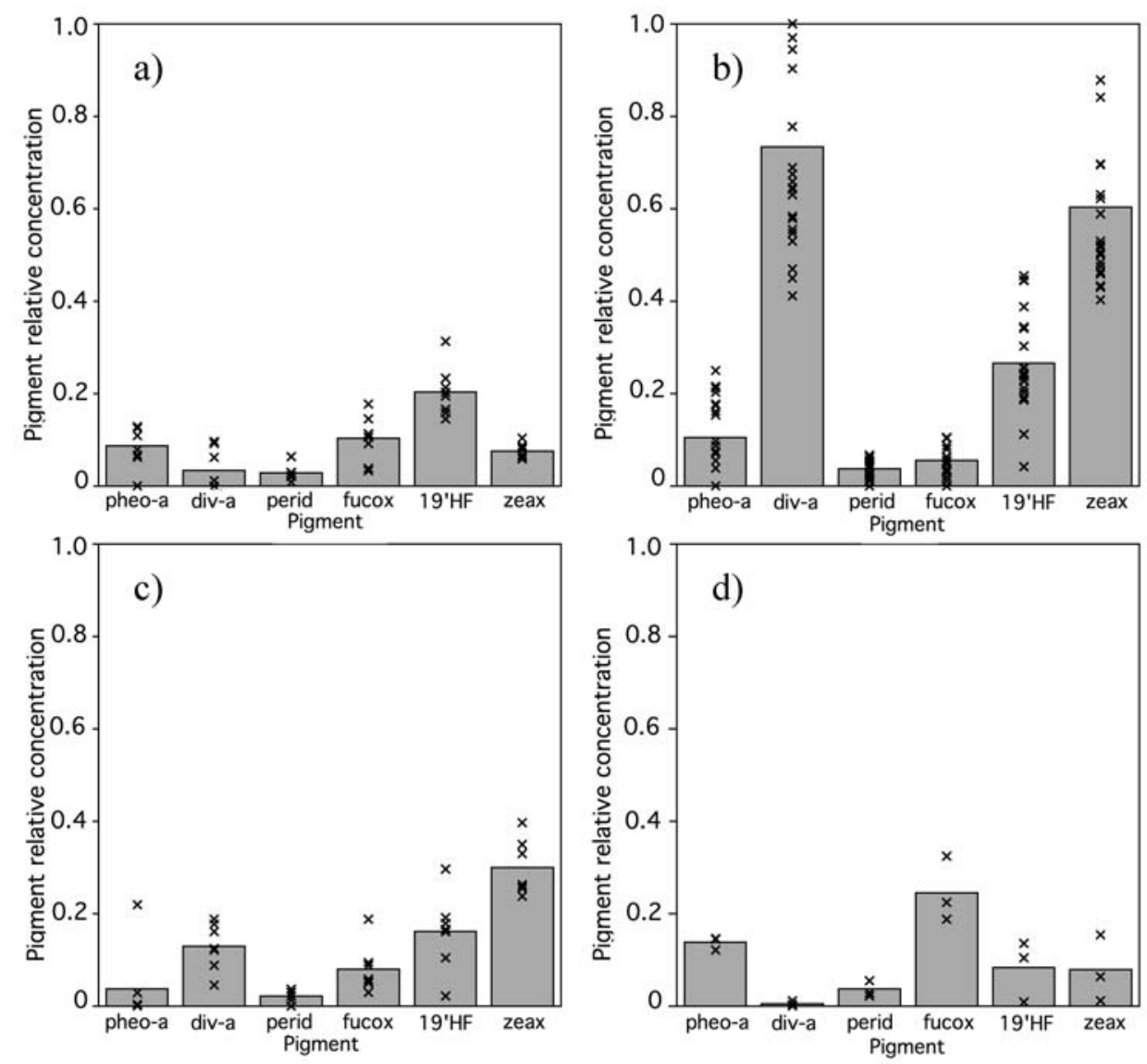

Figure 4. Individual pigment inventories (see Table 1) for the four populations identified, dominated by: a) haptophytes, b) Prochlorococcus, c) SLC, and d) diatoms. Grey bars represent the mean pigment relative concentrations, and black dots show the individual pigment relative concentrations. 


\section{Figure 5}
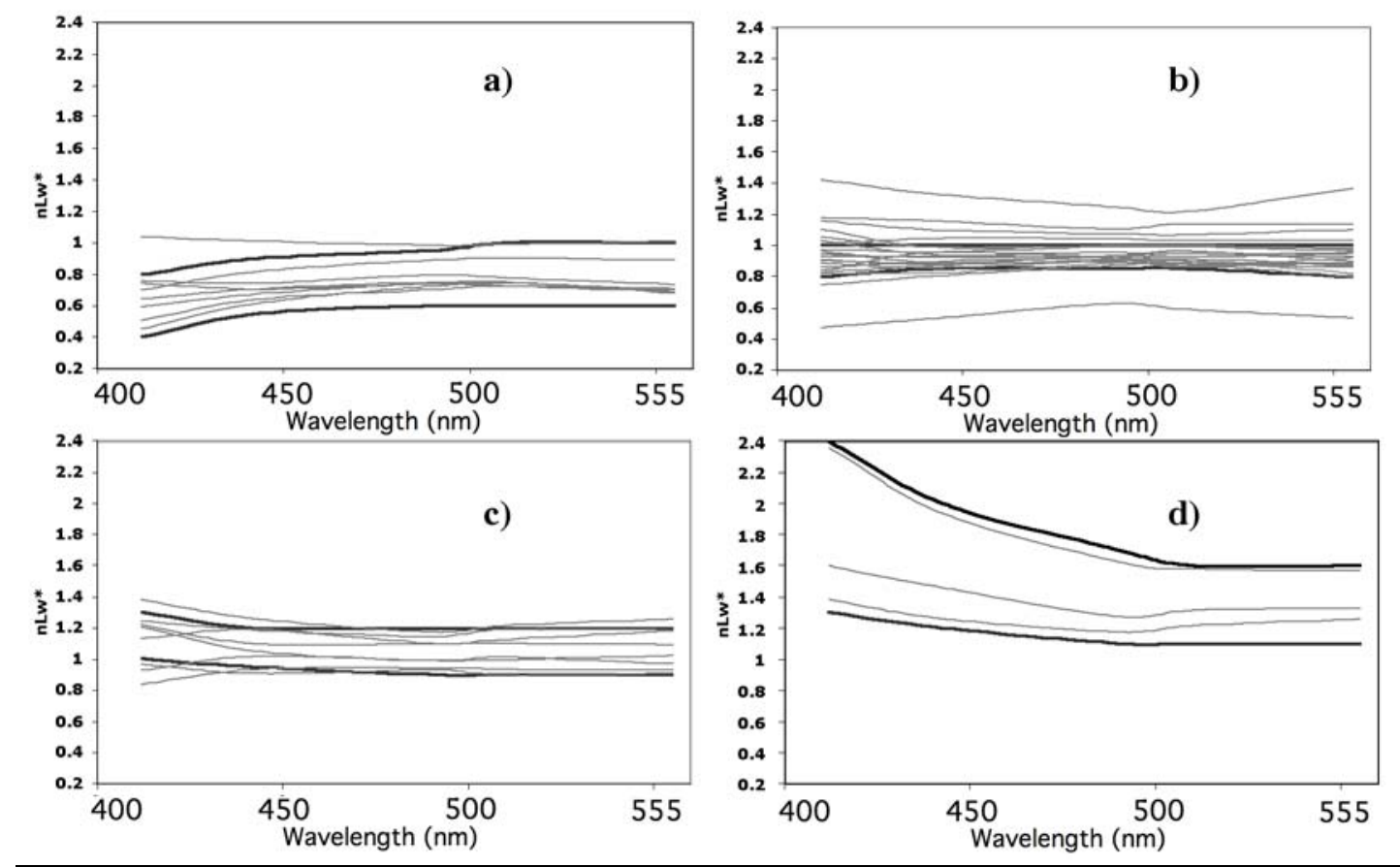

Figure 5. Spectral signatures of $\mathrm{nLw}^{*}$ of the four different phytoplankton assemblages, dominated by a) haptophytes, b) Prochlorococcus, c) SLC, and d) diatoms. Individual SeaWiFS $\mathrm{nLw}^{*}$ are depicted by the grey lines. Bold plain lines show the minimum and maximum spectral values of $\mathrm{nLw}^{*}$ defined in Table 5 to characterize phytoplankton groups. 


\section{Figure 6}
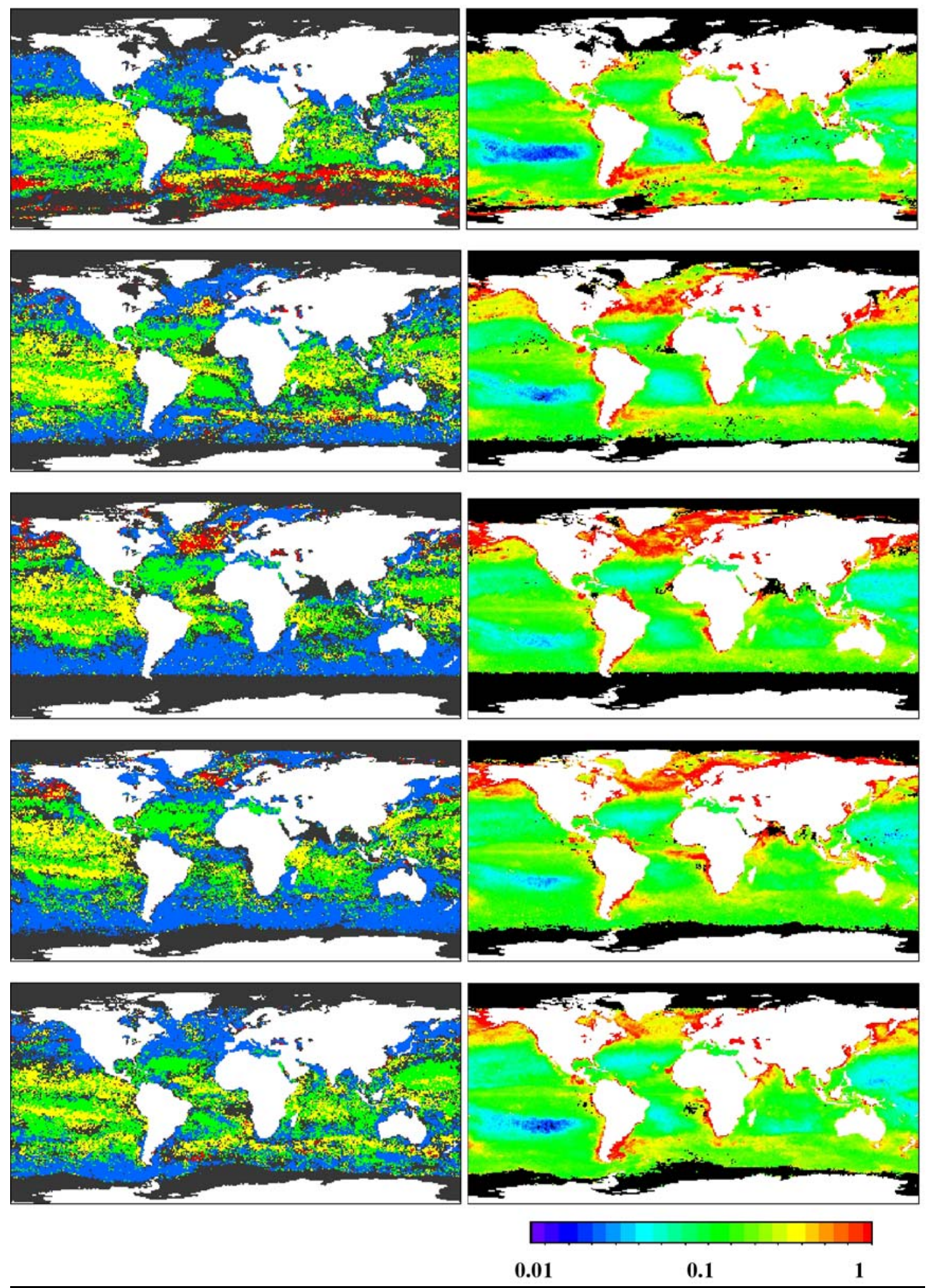

Figure 6. Monthly mean maps of the phytoplankton assemblages (left panels with haptophytes in blue, Prochlorococcus in green, SLC in yellow, and diatoms in red) and of the standard SeaWiFS Chl $a$ (right panels) for January, April, June, August and October 2001. Unidentified pixels are in black. 
Figure 7
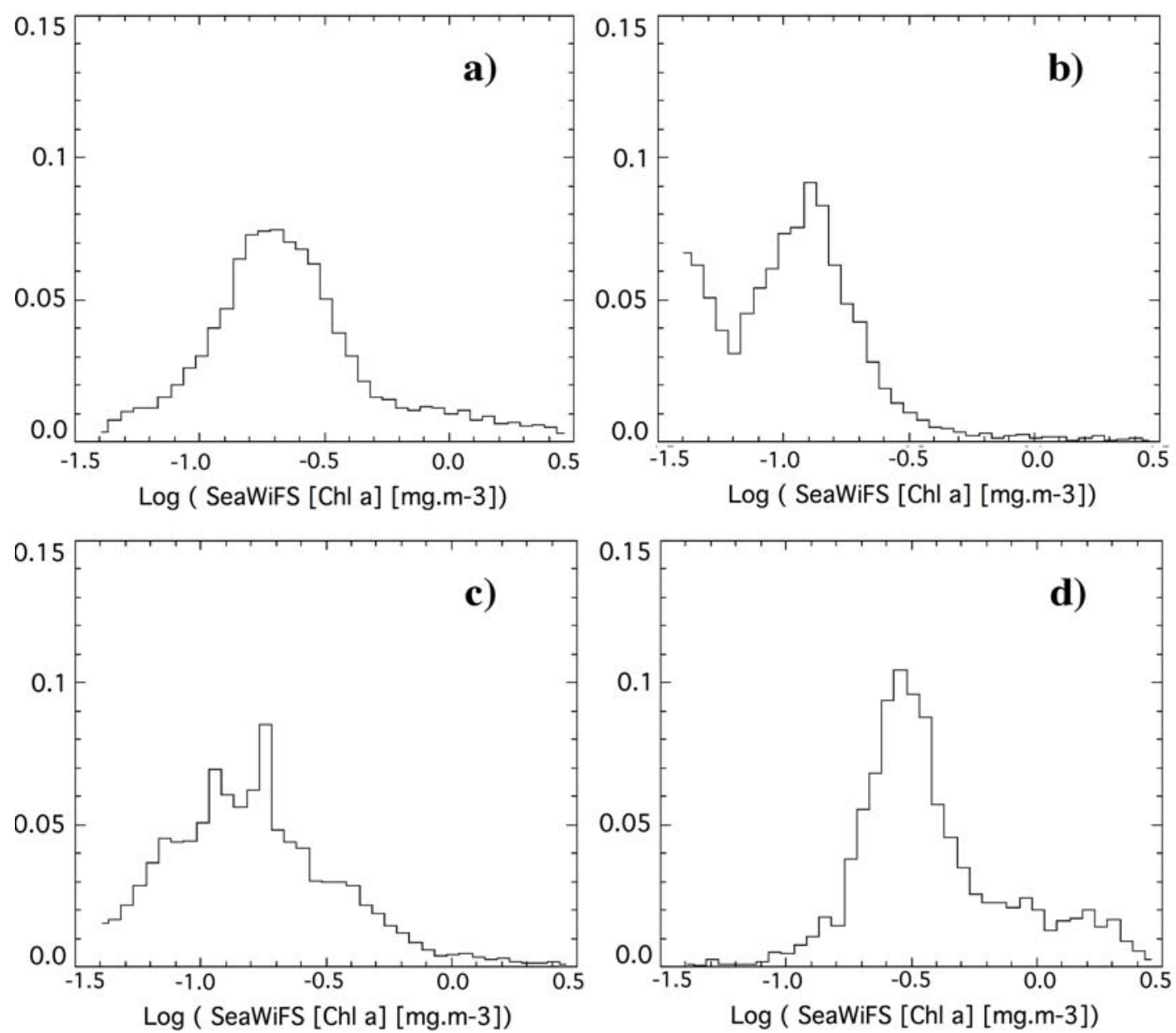

Figure 7. Relative frequency histogram of the SeaWiFS Chl $a$ for year 2001 for the four different phytoplankton assemblages, dominated by: a) haptophytes, b) Prochlorococcus, c) SLC, and d) diatoms. 